\title{
Lung Worms of Wild Boars in the Western Region of Tokyo, Japan
}

\author{
Tatsushi MORITA ${ }^{1)}$, Ken-ichi HARUTA ${ }^{1)}$, Akiko SHIBATA-HARUTA ${ }^{1)}$, Eiji KANDA ${ }^{2)}$, Soichi IMAI ${ }^{1)}$ and \\ Kazunori IKE ${ }^{1)}$ \\ ${ }^{1)}$ Laboratory of Veterinary Parasitology, Nippon Veterinary and Life Science University, Musashino, Tokyo 180-8602 and ${ }^{2)}$ Tokyo \\ Wildlife Research Center, Tokyo 190-0181, Japan
}

(Received 21 July 2006/Accepted 12 December 2006)

ABSTRACT. Prevalence of lung worms belonging to the genus Metastrongylus was surveyed on 42 Japanese wild boars (Sus scrofa leucomystax) captured officially for wildlife damage control in the western parts of Tokyo, Japan from April 2000 to April 2001. The number of parasites was the highest in the caudal lung lobes. Four species, M. elongatus (ME), M. salmi (MS), M. asymmetricus (MA) and M. pudendotectus (MP), were identified. All the boars were infected with 2 or more species, and $64.3 \%$ of the boars had all 4 species. The composition of species, ME:MS:MA:MP=1.3:3.4:1.0:1.4, was drastically different from the previous reports. The peak of the average number of the parasites was observed in the period of January to March 2001 because of the increase of MS. KEY WORDS: Japanese Wildlife, Metastrongylus spp., Sus scrofa leucomystax.

J. Vet. Med. Sci. 69(4): 417-420, 2007

Studies on the prevalences of infectious diseases in wildlife are important to evaluate them as the sources of infectious agents to livestock and human, because the inhabiting area of some wild animals is near the suburbs. Although some cases of lung worm infections in the Japanese wild boars (Sus scrofa leucomystax) have been reported [1-3, 9, $10,13,14]$, the investigated regions were limited only in the western part of Japan before 1984 [3]. We investigated the prevalence of lung worms of the Japanese wild boars captured officially for wildlife damage control in the Metropolis of Tokyo, Japan throughout the year.

Forty-two wild boars including 4 yearlings were shot from April 2000 to April 2001 in the western region of Tokyo, where was surrounded in the points of $35^{\circ} 46^{\prime} 51 \mathrm{~N}$ $139^{\circ} 05^{\prime} 49 \mathrm{E}, 35^{\circ} 40^{\prime} 11 \mathrm{~N} 139^{\circ} 15^{\prime} 50 \mathrm{E}, 35^{\circ} 46^{\prime} 45 \mathrm{~N}$ $139^{\circ} 19^{\prime} 15 \mathrm{E}$ and $35^{\circ} 47^{\prime} 51 \mathrm{~N} 139^{\circ} 08^{\prime} 39 \mathrm{E}$. All specimens showed macroscopical lung lesions such as marginal emphysema and consolidation. These lungs were excised, transported to the laboratory under $4^{\circ} \mathrm{C}$ or $-20^{\circ} \mathrm{C}$, separated to every lobes, and examined along the bronchial tubes for detection of lung worms. The parasites found were put into $70 \%(\mathrm{v} / \mathrm{v})$ ethanol, immersed in lacto-phenol solution to transparentize, then identified according to the descriptions by Holló [5], Noda [9] and Jansen [6].

The number of the parasites in each boar was ranged 4 to 757 (average \pm standard deviation $=136 \pm 147.1$ ). The prevalence of the lung worms obtained in the present survey was $100 \%$ (42 positives/42 samples) as much as the values in the previous reports $(61.5 \%(8 / 13)$ [2], 95.2\% (20/21) [10] and $100 \%(2 / 2)[1])$. The average ratio of the number of parasitized worms in each lung lobe against total worm number in each boar is shown in Fig. 1. Significantly higher numbers of the worms were detected in both sides of the caudal lung lobes, especially in the left caudal lobe, than in the remaining lobes $(\mathrm{p}<0.01$ in Tukey-Kramer's honestly significant difference test after ANOVA [7]). Four species of the genus Metastrongylus, M. elongatus (ME), M. salmi (MS), M. asymmetricus (MA) and M. pudendotectus (MP), were identified (Table 1, Fig. 2), and the incidence of each species was $92.9,100,88.1$ and $71.4 \%$, respectively. All the wild

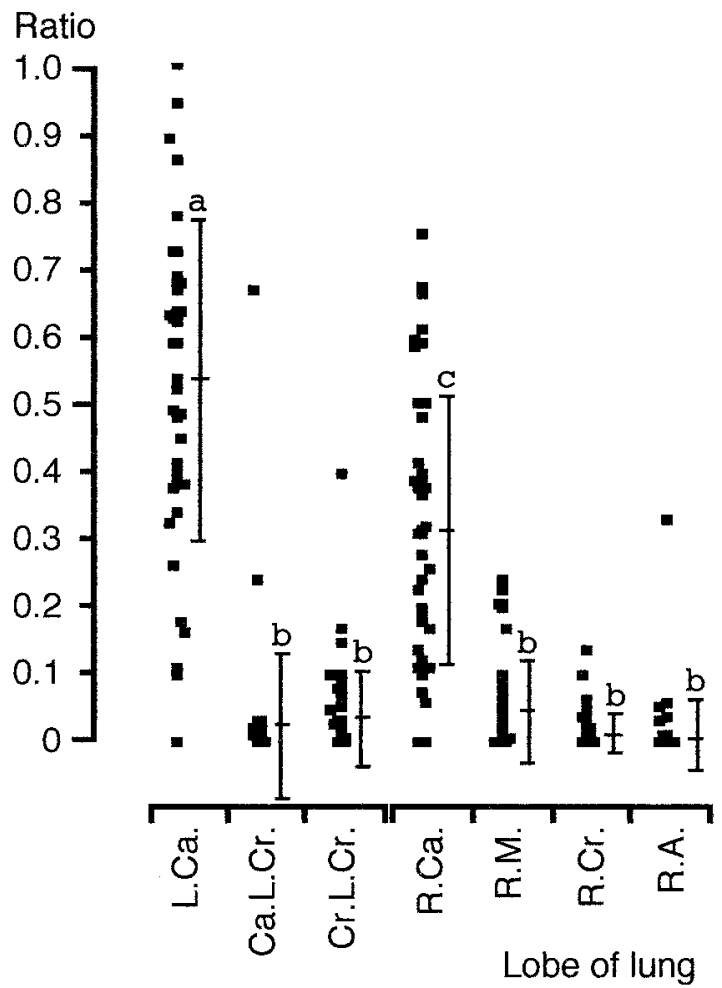

Fig. 1. Ratio of the number of parasitized worms in each lung lobe against total worm number in each boar. Cr., Ca., M., A., L. and R. under the $\mathrm{X}$-axis are abbreviated names of the parts of lung lobe, meaning "cranial", "caudal", "middle", "accessory", "left" and "right", respectively. Dots in the graph indicate the ratio of each boar. Bars indicate average and standard deviation. Different combinations of alphabets shown by every bar indicate significance $(\mathrm{p}<0.01)$. 
Table 1. Measurements of 4 species of the genus Metastrongylus

\begin{tabular}{|c|c|c|c|c|}
\hline & M. elongatus & M. salmi & M. asymmetricus & M. pudendotectus \\
\hline \multicolumn{5}{|l|}{ Male $(n=10)$} \\
\hline Body length (mm) & $\begin{array}{c}10.5-18.5 \\
(15.55 \pm 2.72)\end{array}$ & $\begin{array}{c}10.0-18.0 \\
(13.9 \pm 2.18)\end{array}$ & $\begin{array}{c}11.5-18.5 \\
(15.05 \pm 2.65)\end{array}$ & $\begin{array}{c}13.5-25.0 \\
(18.0 \pm 3.83)\end{array}$ \\
\hline \multicolumn{5}{|l|}{ Spicule } \\
\hline $\begin{array}{l}\text { Length }(\mathrm{mm}) \\
\text { Barb of terminal }\end{array}$ & $\begin{array}{c}3.73-4.73 \\
(4.08 \pm 0.284) \\
\text { single }\end{array}$ & $\begin{array}{c}2.05-2.56 \\
(2.22 \pm 0.160) \\
\text { single }\end{array}$ & $\begin{array}{c}0.57-0.88 \\
(0.68 \pm 0.084) \\
\text { double }\end{array}$ & $\begin{array}{c}1.07-1.24 \\
(1.18 \pm 0.065) \\
\text { double }\end{array}$ \\
\hline Gubernaculum length $(\mu \mathrm{m})$ & ND & ND & $\begin{array}{c}30-45 \\
(37.5 \pm 6.45)\end{array}$ & $\begin{array}{c}30-40 \\
(36.25 \pm 4.79)\end{array}$ \\
\hline Genital cone & $\begin{array}{l}\text { Strongly developed, } \\
\text { tip bent ventrally }\end{array}$ & $\begin{array}{c}\text { Considerably } \\
\text { developed }\end{array}$ & Weakly developed & Weakly developed \\
\hline Cloaca & $\begin{array}{l}\text { On median line } \\
\text { of body }\end{array}$ & $\begin{array}{l}\text { On median line } \\
\text { of body }\end{array}$ & $\begin{array}{l}\text { Shifted to left side } \\
\text { of body }\end{array}$ & $\begin{array}{l}\text { On median line } \\
\text { of body }\end{array}$ \\
\hline \multicolumn{5}{|l|}{ Bursa copulatrix } \\
\hline Length $(\mu \mathrm{m})$ & $\begin{array}{c}320-420 \\
(357.1 \pm 40.3)\end{array}$ & $\begin{array}{c}470-540 \\
(510 \pm 23.1)\end{array}$ & $\begin{array}{c}470-570 \\
(533.8 \pm 32.9)\end{array}$ & $\begin{array}{c}480-590 \\
(541 \pm 38.1)\end{array}$ \\
\hline Width $(\mu \mathrm{m})$ & $\begin{array}{c}290-250 \\
(269.3 \pm 16.9)\end{array}$ & $\begin{array}{c}310-350 \\
(325.7 \pm 14.0)\end{array}$ & $\begin{array}{c}320-450 \\
(382.5 \pm 48.9)\end{array}$ & $\begin{array}{c}380-460 \\
(433.3 \pm 25.0)\end{array}$ \\
\hline \multicolumn{5}{|l|}{ Female $(n=10)$} \\
\hline Body length & $\begin{array}{c}29.5-45.5 \\
(38.55 \pm 4.85)\end{array}$ & $\begin{array}{c}24.5-32.0 \\
(28.7 \pm 2.20)\end{array}$ & $\begin{array}{c}16.5-26.0 \\
(21.8 \pm 2.80)\end{array}$ & $\begin{array}{c}22.5-30.5 \\
(26.67 \pm 2.53)\end{array}$ \\
\hline Vulva & $\begin{array}{l}\text { Somewhat anterior to } \\
\text { anus and postero-dorsal } \\
\text { to prevulvar swelling }\end{array}$ & $\begin{array}{l}\text { Somewhat anterior to } \\
\text { anus and postero-dorsal } \\
\text { to prevulvar swelling }\end{array}$ & $\begin{array}{l}\text { On ventral base of } \\
\text { prevulvar swelling }\end{array}$ & $\begin{array}{l}\text { Near to anus and } \\
\text { postero-dorsal to } \\
\text { prevulvar swelling }\end{array}$ \\
\hline Prevulvar cuticular dilatation & absent & absent & present & present \\
\hline Prevulvar swelling & Hemispherical & $\begin{array}{c}\text { Flattened- } \\
\text { hemispherical }\end{array}$ & $\begin{array}{l}\text { Set off sharply from } \\
\text { body anteriorly }\end{array}$ & $\begin{array}{l}\text { Set off sharply from } \\
\text { body anteriorly }\end{array}$ \\
\hline Tail length $(\mu \mathrm{m})$ & $\begin{array}{c}50-100 \\
(78 \pm 15.85)\end{array}$ & $\begin{array}{c}75-100 \\
(88.5 \pm 10.55)\end{array}$ & $\begin{array}{c}135-210 \\
(168 \pm 21.11)\end{array}$ & $\begin{array}{c}105-165 \\
(142 \pm 16.54)\end{array}$ \\
\hline $\begin{array}{l}\text { Eggs in vagina } \\
\text { Length }(\mu \mathrm{m})\end{array}$ & $\begin{array}{c}45.0-55.0 \\
(49.75 \pm 2.59)\end{array}$ & $\begin{array}{c}46-55 \\
(49.9 \pm 3.06)\end{array}$ & $\begin{array}{c}50-57 \\
(53.0 \pm 2.40)\end{array}$ & $\begin{array}{c}54-66 \\
(59.0 \pm 4.1)\end{array}$ \\
\hline Width $(\mu \mathrm{m})$ & $\begin{array}{c}33.5-38.0 \\
(35.55 \pm 1.44)\end{array}$ & $\begin{array}{c}20.5-40 \\
(34.0 \pm 5.25)\end{array}$ & $\begin{array}{c}29.0-42.5 \\
(37.2 \pm 4.20)\end{array}$ & $\begin{array}{c}34.5-52.5 \\
(40.9 \pm 5.0)\end{array}$ \\
\hline
\end{tabular}

* Numerical values present as range with average \pm standard deviation in parentheses.

* ND: not detected.

boars were infected with 2 or more species, and the combination ratios of the appeared species were; all 4 species: 64.3\%, 3 species: $23.8 \%$ (ME \& MS \& MA=16.7\% and ME $\& \mathrm{MS} \& \mathrm{MP}=7.1 \%)$ and 2 species: $11.9 \%(\mathrm{ME} \& \mathrm{MS}=4.8 \%$ and $\mathrm{MS} \& \mathrm{MA}=7.1 \%$ ). The other combinations were not found. The composition of the species, ME:MS:MA:MP = $1.3: 3.4: 1.0: 1.4$, was different from the previous reports (ME:MS:MA:MP =4.4:2.6:1.0:0 [3]; = 4.8:2.4:1.0:0 [9]) in the points of the most frequent species (MS instead of ME) and a presence of MP. Although MP was already reported with MA in Japan [2], its incidence has not been presented. It is difficult to explain these differences because the dominant species of lung worms in the wild boars or cross-bred pigs vary depending on countries, e.g. MP in Germany [8], MS in Ghana [11] and ME in Florida [4] and Iran [12].

The seasonal change in the intensity of infection in each species is shown in Fig. 3. The peak of the average number of the parasites was observed on the period of January to March 2001 because of the increase of MS, but there was no significant difference among the seasonal changes of each species by ANOVA. This seasonal analysis could not be compared with the other Japanese cases because no such information has been presented in Japan. However, Foster et al. [4] reported that the peak intensity in the feral swine in Florida was observed on the period of October to December because of the increase of ME among of the detected three species (ME, MS and MP). The difference between the results in the present survey and previous reports $[2-4,9$, 10] would be attributed to the geographical and/or the temporal difference. More intensive and periodical investigation should be carried out to confirm the differences. 


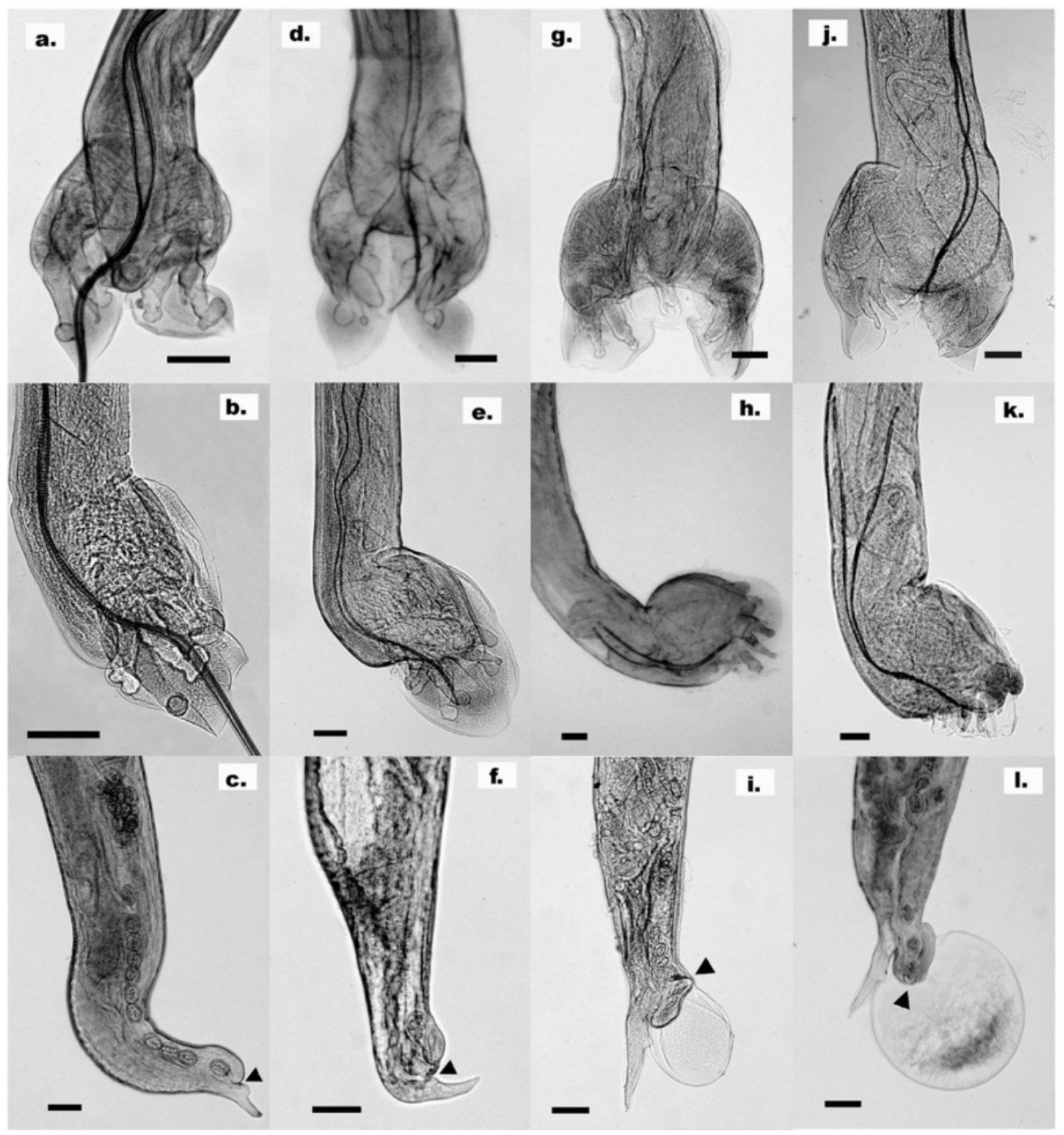

Fig. 2. Morphological features of the caudal end of 4 Metastrongylus spp. collected. a-c: M. elongatus, d-f: M. salmi, g-i: M. asymmetricus and $\mathrm{j}-\mathrm{l}:$ M. pudendotectus. a, d, $\mathrm{g}$ and $\mathrm{j}$ : ventral view, b, e, h and $\mathrm{k}$ : lateral view of male. $\mathrm{c}, \mathrm{f}, \mathrm{i}$ and $\mathrm{l}$ : female lateral view with an arrow head indicating the vulval opening. Bar $=100 \mu \mathrm{m}$. 

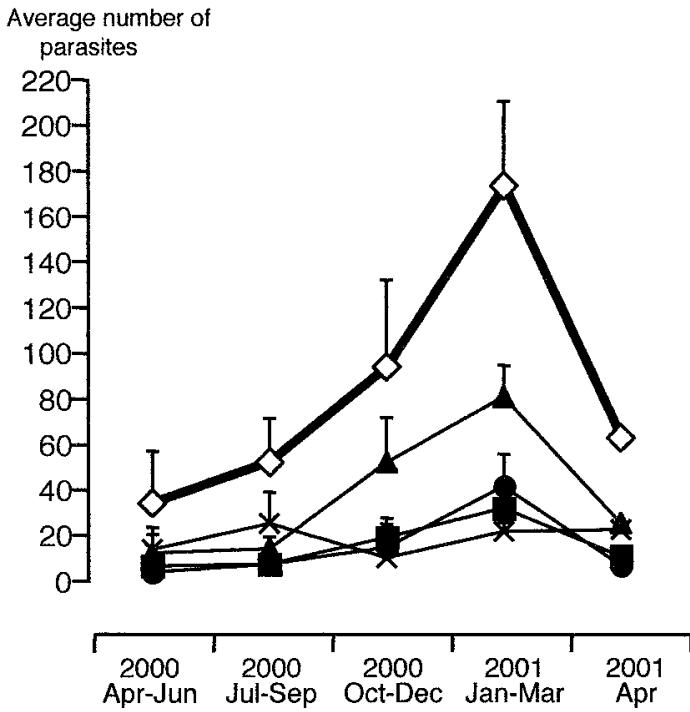

(3)

(11)

\section{REFERENCES}

1. Ashizawa, H., Habe, S., Yamaguchi, M., Ogihara, T., Nosaka, D., Tateyama, S. and Kimura, S. 1980. Bull. Fac. Agric. Miyazaki Univ. 27: 217-223 (in Japanese with English summary).

2. Ashizawa, H. and Moritomo, Y. 1989. Proc. Fac. Agric. Kyushu Tokai Univ. 8: 85-93 (in Japanese with English summary).

3. Chinone, S., Itagaki, H., Hishino, C. and Imaoka, H. 1984. Bull Azabu Univ. Med. 5: 109-118.

4. Forester, D. J., Porter, J. H. and Frankenberger, W. B. 1982. JVMA 181: 1278-1280

5. Holló, F. 1965. Acta Vet. Hung. 15: 259-268.

6. Jansen, J. Jr. 1964. T. Diergeneesk. 89: 1205-1211.

7. Kramer, C. Y. 1956. Biometrics 12: 307-310.

8. Mennerich-Bunge, B., Pohlmeyer, K. and Stoye, M. 1993. Berl. Münch. Tierärztl. Wschr. 106: 203-207.

9. Noda, R. 1973. Bull. Univ. Osaka Pref., Ser. B 25: 21-29.

10. Ono, Y., Kuba, N., Kimura, S. and Kayama, R. 1957. Sci. Reports Hyogo Univ. Agric. Ser. Zootech. Sci. 3: 41-57 (in Japanese with English summary).

11. Permin, A., Yelifari, L., Bloch, P., Steenhard, N., Hansen, N.P. and Nansen, P. 1999. Vet. Parasitol. 87: 63-71.

Fig. 3. Seasonal changes in the average intensity of infection. $\diamond$ : all species, $\square$ : M. elongatus, $\mathbf{\Delta}:$ : salmi, $\times: M$. asymmetricus, $\mathbf{0}$. pudendotectus. Bar $=$ standard error of means. Numbers of examined animals on each season show in the parenthesis under the $\mathrm{X}$ axis. Seasonal differences are not significant statistically.

12. Solaymani-Mohammadi, S., Mobedi, I., Rezaian, M., Massoud, J., Mohebali, M., Hooshyar, H., Ashrafi, K. and Rokni, M.B. 2003. J. Helminthol. 77: 263-267.

13. Uchida, K., Uchida, A. and Itagaki, H. 1984. Bull. Azabu Univ. Vet. Med. 5: 119-131 (in Japanese with English summary).

14. Yamaguti, S. 1935. Jpn. J. Zool. 6: 433-457. 